\title{
The Effect of Use of Microalgae [Chlorella vulgaris Beyerinck (Beijerinck)] in Different Fertilizer Applications on Plant Growth of Garden Rocket (Eruca vesicaria ssp. sativa Mill.)
}

\author{
Aynur Sadak Turhan ${ }^{1, a, *}$, Büşra Günsan Can ${ }^{1, b}$, Turgay Kabay ${ }^{2, c}$, Suat Şensoy ${ }^{2, d}$ \\ ${ }^{1}$ Horticultural Sciences, The Institute of Natural and Applied Sciences, Van Yüzüncü Yıl University, 65090 Van, Turkey \\ ${ }^{2}$ Horticulture Department, Agricultural Faculty, Van Yüzüncü Yll University, 65090 Van, Turkey \\ *Corresponding author
}

\begin{tabular}{|c|c|}
\hline A R T I C L E I N F O & A B S T R A C T \\
\hline $\begin{array}{l}\text { Keywords: } \\
\text { Bio-fertilizer } \\
\text { Garden rocket } \\
\text { Microalgae } \\
\text { Nutrient content }\end{array}$ & 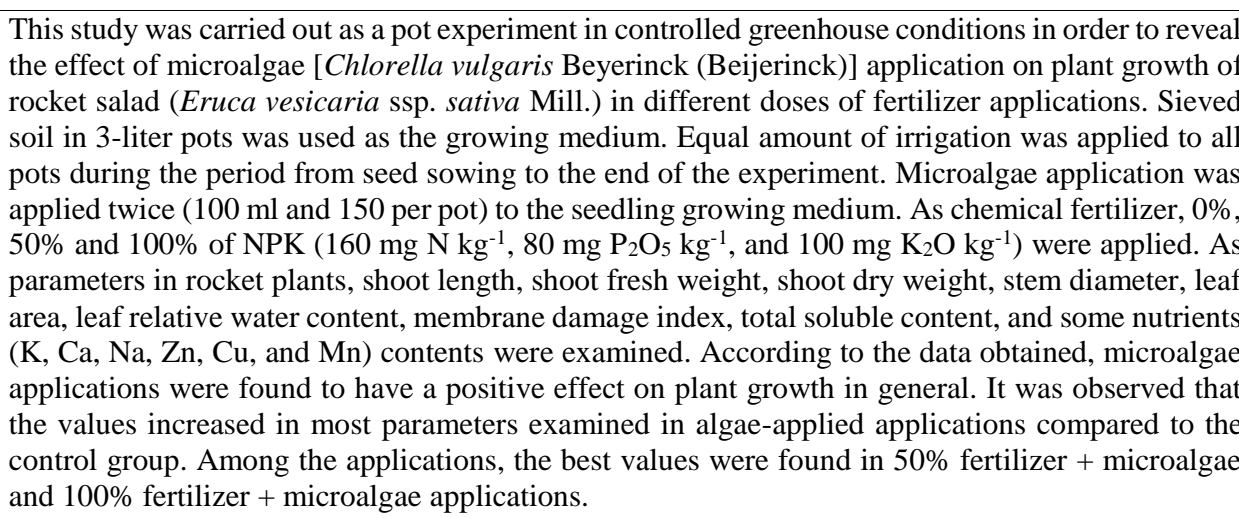 \\
\hline
\end{tabular}

Plant growth

and $100 \%$ fertilizer + microalgae applications.

\section{Introduction}

In response to the increasing population in the world, the need for food is increasing rapidly and continuously (Sencar, 1988; Engin et al., 2019). Achieving balanced and adequate diet is gradually becoming a problem (Özdemir, 2014). Despite the continuous increase in the world population, either it is necessary to increase the agricultural areas or to increase the amount of products obtained from the unit area (Midmore, 1993; Ergun et al., 2020).

Eruca vesicaria ssp. sativa Mill. commonly known as garden rocket, salad rocket or arugula, is an annual plant, native to Mediterranean Basin and it is cool season salad vegetable with a unique, rich aroma, taste, and nutritious components, as in other members of the Brassicaceae family (Morales and Janick, 2002; Beck, 2005; Salk et al., 2008; Eşiyok, 2012; Barazani and Ziffer-Berger, 2014). Garden rocket, which has a rich content of vitamins, is also important in terms of human nutrition and it is known that it is good for some diseases (eye infections, night blindness, etc.) due to the vitamins $\mathrm{A}$ and $\mathrm{C}$ it contains (Balc1, 2019). Garden rocket, which is becoming increasingly important, comprises a wide variety of phytochemicals that promote health (Kusvuran and Ellialtioglu, 2021); therefore, garden rocket production and consumption has increased significantly in recent years in the world and Turkey (Temel, 2016; Hassan et al., 2017).

Some soils are poor in terms of organic matter due to the effect of climate or other factors (Kacar, 1997). The use of intensive chemical fertilizers in agricultural areas causes deterioration of soil structure and pollution of underground water resources (Turan, 2007). In agricultural production, it is very important to use sustainable resources correctly in terms of human and environmental health (Cirik and Cirik, 1999). Excessive use of chemicals in agricultural lands disrupts the ecological balance. New solutions to the 
problems encountered in agriculture must be sustainable (Koru and Cirik, 1999). Different microalgae used in recent years are considered as sustainable plant nutrient sources (Okur et al., 2001). Fertilization strategies are important for lowering hazardous substances in leafy vegetables such as garden rocket (Santamaria, 1998). Moreover, it is wise to use bio-stimulants for reducing nutrient amount in agricultural production systems (Vernieri et al., 2006).

The positive effect of microalgae on plant growth is becoming noticeable (Kut et al., 2007). Microalgae, which are used as plant nutrients, produce quality products in agricultural crops. Considering the increase in yield and quality, microalgae have been used as bio-fertilizers in agriculture (Engin et al., 2019), and there has been increasing use of microalgae-based fertilizers (Eşiyok et al., 2001). Approximately 1 million tons of microalgae are used in soil enrichment programs in the world (Engin et al., 2019). The use of some bio-fertilizers in terms of sustainability in agricultural lands increases the quality and yield because it is known that it increases nutrient uptake in the soil (Kut et al., 2007). The aim of this study was to reveal the effects of using fewer chemical fertilizers, thus saving fertilizer and protecting the environment, through the use of microalgae in garden rocket (Eruca vesicaria ssp. sativa Mill.), as well as revealing the effects of microalgae on plant growth and some nutritional content of garden rocket.

\section{Materials and Methods}

In the present study, the effect of microalgae [Chlorella vulgaris Beyerinck (Beijerinck)] use on plant growth in garden rocket [Eruca vesicaria ssp. sativa Mill. cv. Rota (Sim Arzuman Seeds)] was investigated. The study was carried out as a pot experiment in controlled greenhouse conditions $\left(15 \pm 4^{\circ} \mathrm{C}\right.$ night and $28 \pm 4^{\circ} \mathrm{C}$ day). Microalgae application was applied twice $(100 \mathrm{ml}$ and 150 per pot) to the seedling growing medium and as chemical fertilizer, $0 \%, 50 \%$ and $100 \%$ of NPK (160 mg N kg $\mathrm{kg}^{-1}$, and $100 \mathrm{mg} \mathrm{K}_{2} \mathrm{O} \mathrm{kg}{ }^{-1}$ as 20:20:20 NPK, Potassium sulphate, and urea) were applied as base fertilizer and 40

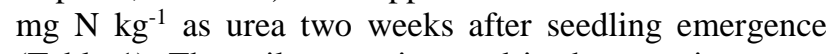
(Table 1). The soil properties used in the experiment are given in Table 1.

Sieved soil in 3-liter pots was used as the growing medium, and 40 seeds were sown to each pot. Equal amount of irrigation was applied to all pots during the period from seed sowing to the end of the experiment, is about 6.5 weeks.

\section{Cultivation and Application of Microalgae}

The microalgae [Chlorella vulgaris Beyerinck (Beijerinck)] used in the present study were obtained from Cukurova University, Faculty of Fisheries and cultured in a tissue culture laboratory at Van Yuzuncu Yil University. Bold Wynne nutrient medium $\left(\mathrm{NaNO}_{3}-0.250 \mathrm{~g}\right.$; $\mathrm{MgSO}_{4} .7 \mathrm{H}_{2} \mathrm{O}-0.075 \mathrm{~g} ; \mathrm{K}_{2} \mathrm{HPO}_{4}-0.075 \mathrm{~g} ; \mathrm{KH}_{2} \mathrm{PO}_{4-} 0.0175$ $\mathrm{g}$; NaCl-0.025 g; $\mathrm{CaCl}_{2} . \mathrm{H}_{2} \mathrm{O}-0.025 \mathrm{~g} ; 1000 \mathrm{ml}$ of Distilled Water) was used in the production of bulk cultures (Duygu et al., 2017). The nutrient medium prepared in $1000 \mathrm{ml}$ was equally divided into two $500 \mathrm{ml}$ flasks, autoclaved at $121^{\circ} \mathrm{C}$ for 20 minutes to ensure sterilization and their cultivation was carried out in a sterile cabinet. Microalgae was cultured with $9 \mathrm{ml}$ of medium $+1 \mathrm{ml}$ of suspended culture. The sowing of the bulk cultures was started with $500 \mathrm{ml}$ and then transferred to $1000 \mathrm{ml}$ nutrient medium. In order to prevent contamination and at the same time to ensure air circulation, the mouth of the flasks was not completely closed, but the cotton that was sterilized in an autoclave was placed (Ağırman, 2015). After the first two days, the cultures were aired with an aquarium pump to keep the bulk cultures in suspension. The light needs of the cultures were met with artificial lighting with a light source (150 $\mu \mathrm{mol} \mathrm{m} \mathrm{m}^{-2} \cdot \mathrm{s}^{-1}$ ) was placed at a distance of $22 \mathrm{~cm}$ from the cultures, horizontally, from behind. Cultures were treated with a $16: 8$ light/dark period and grown at $22-25^{\circ} \mathrm{C}$ at room temperature. Cell counts were performed using a Thoma slide. Chlorella vulgaris Beyerinck (Beijerinck) algae was applied at the rate of $2 \times 10^{7}$ algae $1^{-1}$ to the half of the application twice (at seed sowing and 20 days after as $100 \mathrm{ml}$ and $150 \mathrm{ml}$, respectively) (Aydoner et al., 2018; Ergun et al., 2020).

\section{The Studied Parameters as Follow:}

Shoot fresh and dry weight $(g)$

The fresh weight was determined by weighing the garden rocket plants in each pot with a weighing scale with a precision of $0.1 \mathrm{~g}$. The same samples were left open for 24 hours, then dried in an oven at $65^{\circ} \mathrm{C}$ for 48 hours to dry thoroughly, and the dry weight was determined by measuring on a weighing scale with $0.1 \mathrm{~g}$ sensitivity.

Table 1. Applications and soil properties

\begin{tabular}{|c|c|c|}
\hline Application\# & Application content & \\
\hline $\begin{array}{l}1 \\
2 \\
3 \\
4 \\
5 \\
6\end{array}$ & $\begin{array}{c}\text { Control (no microalgae and no fertilizer) } \\
\% 50 \text { chemical fertilizer } \\
\% 100 \text { chemical fertilizer } \\
\text { Microalgae } \\
\% 50 \text { chemical fertilizer + Microalgae } \\
\% 100 \text { chemical fertilizer + Microalgae }\end{array}$ & \\
\hline Soil properties & Amount & Level \\
\hline $\begin{array}{l}\text { Potassium }\left(\mathrm{K}_{2} \mathrm{O}\right) \mathrm{kg} \mathrm{ha}^{-1} \\
\text { Phosphor }\left(\mathrm{P}_{2} \mathrm{O}_{5}\right) \mathrm{kg} \mathrm{ha}^{-1} \\
\text { Lime }(\%) \\
\text { Organic Matter (\%) } \\
\text { Total salt }(\%) \\
\text { pH }\end{array}$ & $\begin{array}{c}580.2 \\
31.2 \\
11.025 \\
1.98 \\
0.036 \\
7.21\end{array}$ & $\begin{array}{l}\text { High } \\
\text { Little } \\
\text { Medium } \\
\text { Little } \\
\text { No salt } \\
\text { Neutral }\end{array}$ \\
\hline
\end{tabular}


Table 2. Effect of microalgae application on plant growth of garden rocket grown with different doses of chemical fertilizer

\begin{tabular}{|c|c|c|c|c|c|c|}
\hline \multirow{3}{*}{ Chemical Fertilizer } & \multicolumn{3}{|c|}{ Shoot fresh weight $\left(\mathrm{g} \mathrm{pot}^{-1}\right)$} & \multicolumn{3}{|c|}{ Shoot dry weight $\left(\mathrm{g} \mathrm{pot}^{-1}\right)$} \\
\hline & \multicolumn{2}{|c|}{ Microalgae } & \multirow{2}{*}{ Mean } & \multicolumn{2}{|c|}{ Microalgae } & \multirow{2}{*}{ Mean } \\
\hline & - & + & & - & + & \\
\hline $0 \%$ (Control) & $8.63^{\mathrm{ns}}$ & 13.14 & $10.89^{\mathrm{B} * *}$ & $1.40^{\mathrm{ns}}$ & 1.56 & $1.48^{\mathrm{B} * *}$ \\
\hline $50 \%$ & 33.84 & 38.62 & $36.23^{\mathrm{A}}$ & 3.47 & 3.55 & $3.51^{\mathrm{A}}$ \\
\hline $100 \%$ & 36.31 & 37.20 & $36.76^{\mathrm{A}}$ & 3.26 & 3.46 & $3.36^{\mathrm{A}}$ \\
\hline Mean & $26.26^{\mathrm{ns}}$ & 29.65 & & $2.71^{\mathrm{ns}}$ & 2.86 & \\
\hline \multirow{3}{*}{ Chemical Fertilizer } & \multicolumn{3}{|c|}{ Stem diameter $(\mathrm{mm})$} & \multicolumn{3}{|c|}{ Shoot height $(\mathrm{cm})$} \\
\hline & \multicolumn{2}{|c|}{ Microalgae } & \multirow{2}{*}{ Mean } & \multicolumn{2}{|c|}{ Microalgae } & \multirow{2}{*}{ Mean } \\
\hline & - & + & & - & + & \\
\hline $0 \%$ (Control) & $1.50^{\mathrm{ns}}$ & 2.15 & $1.83^{\mathrm{B} * *}$ & $10.50^{\mathrm{ns}}$ & 11.50 & $11.00^{\mathrm{B}^{* *}}$ \\
\hline $50 \%$ & 2.03 & 2.96 & $2.49^{\mathrm{A}}$ & 15.50 & 19.75 & $17.63^{\mathrm{A}}$ \\
\hline $100 \%$ & 1.84 & 2.10 & $1.97^{\mathrm{B}}$ & 17.00 & 20.25 & $18.63^{\mathrm{A}}$ \\
\hline Mean & $1.79^{\mathrm{B}^{* *}}$ & $2.40^{\mathrm{A}}$ & & $14.33^{\mathrm{B} * *}$ & $17.17^{\mathrm{A}}$ & \\
\hline \multirow{3}{*}{ Chemical Fertilizer } & \multicolumn{3}{|c|}{ TSS $\left(\right.$ Brix $\left.^{0}\right)$} & \multicolumn{3}{|c|}{ Leaf area $\left(\mathrm{cm}^{2}\right.$ plant $\left.^{-1}\right)$} \\
\hline & \multicolumn{2}{|c|}{ Microalgae } & \multirow{2}{*}{ Mean } & \multicolumn{2}{|c|}{ Microalgae } & \multirow{2}{*}{ Mean } \\
\hline & - & + & & - & + & \\
\hline $0 \%$ (Control) & $3.25^{\mathrm{cd} *}$ & $5.97^{\mathrm{a}}$ & $4.61^{\mathrm{ns}}$ & $16.60^{\mathrm{d}^{* *}}$ & $13.90^{\mathrm{e}}$ & $15.25^{\mathrm{C}^{* *}}$ \\
\hline $50 \%$ & $3.47^{\mathrm{c}}$ & $4.52^{b}$ & 4.00 & $30.63^{c}$ & $41.95^{\mathrm{a}}$ & $36.29^{\mathrm{B}}$ \\
\hline $100 \%$ & $3.57^{\mathrm{c}}$ & $4.45^{\mathrm{b}}$ & 4.01 & $36.83^{b c}$ & $39.80^{\mathrm{b}}$ & $38.31^{\mathrm{A}}$ \\
\hline Mean & $3.43^{\mathrm{B}^{* *}}$ & $4.98^{\mathrm{A}}$ & & $28.02^{\mathrm{B} * *}$ & $31.88^{\mathrm{A}}$ & \\
\hline
\end{tabular}

ns: not significant, *: Significant at $\mathrm{P} \leq 0.05$, **: Significant at $\mathrm{P} \leq 0.01$

\section{Shoot height $(\mathrm{cm})$ and Stem diameter $(\mathrm{mm})$}

The shoot length was measured with a ruler with a precision of $1 \mathrm{~mm}$. The stem diameter was determined with a caliper in $\mathrm{mm}( \pm 0.5)$.

\section{Leaf Area $\left(\mathrm{cm}^{2} /\right.$ plant $)$}

Garden rocket leaves with a known circle area were weighed. Then, the leaf area of the plant was calculated by proportioning the leaf weight of the whole plant according to this area and weight relationship (Kuşvuran, 2010).

\section{Determination of Leaf Relative Water Content $($ LRWC) (\%)}

The relative water content of the leaves and the turgor weights of the leaf samples taken from the plants were determined after they were kept in distilled water for 4 hours after the leaf fresh weights were weighed on a weighing scale with an accuracy of $0.1 \mathrm{~g}$. Then, after the same leaves were kept in an oven at $65^{\circ} \mathrm{C}$ for 48 hours, were weighted again and the relative water content of the leaves was determined as following (Kuşvuran, 2010).

$$
\mathrm{LTWC}=(\mathrm{FW}-\mathrm{DW}) /(\mathrm{TW}-\mathrm{DW}) \times 100
$$

There;

$$
\begin{aligned}
& \text { FW: Fresh Weight } \\
& \text { DW: Dry Weight } \\
& \text { TW: Turgor Weight }
\end{aligned}
$$

\section{Membrane Damage Index (MDI) (\%)}

Samples were taken from garden rocket leaves with a disc sample with a diameter of $17 \mathrm{~mm}$, and EC was measured after they were kept in distilled water for 5 hours. Membrane damage index value was obtained by measuring the EC value again after the same disc samples were kept in a boiling water bath at $100{ }^{\circ} \mathrm{C}$ for 10 minutes (Kuşvuran, 2010).

$$
\mathrm{MDI}=(\mathrm{Lt}-\mathrm{Lc} / 1-\mathrm{Lc}) \times 100
$$

There;

Lt: EC of stressed plant leaf before autoclaving/ EC after autoclaving

Lc: EC of control plant leaf before autoclaving/ EC after autoclaving

\section{Amount of Total Soluble Solid Content (TSS brix ${ }^{0}$ )}

After taking samples from garden rocket plants extracted with a blender, the Then TSS was determined with a hand refractometer (Atago PAL-1, Tokyo, Japan).

\section{Plant Nutrient Analysis}

The plant samples were in an oven $\left(65^{\circ} \mathrm{C}\right)$ for constant weight. The 0.5 grams of dried and grinded samples were pre-burned with $1 \mathrm{ml}$ of ethyl alcohol in crucibles and the samples were burned in a muffle furnace at $500{ }^{\circ} \mathrm{C}$ for 9 12 hours. $4 \mathrm{ml}$ of $3 \mathrm{~N} \mathrm{HCl}$ was mixed with the obtained ash. The samples were left on the hot plate and kept on it until they turned yellow. When the yellow color was formed, the crucibles taken from the hot plate were transferred to the volumetric flask with the help of the filtering set and the samples were made ready for reading (Kacar, 1997; Kacar and İnal, 2008).

\section{Statistical Analysis}

In the study, IBM SPSS 21.0 package program was used for variance analysis in order to compare the data obtained from the average of different doses of fertilizer applications and microalgae applications. T-test was applied for the differences between microalgae applications, and Duncan multiple range test was used for fertilizer applications (Duncan, 1955).

\section{Results and Discussion}

In the present study, the effect of different doses of chemical fertilizer and microalgae application on the growth of garden rocket (Eruca vesicaria ssp. sativa Mill.) 
was investigated. It has been determined that microalgae applications have a positive effect on plant growth in general and some noticeable parameters are discussed below. The data about shoot fresh and dry weight, shoot length, stem diameter, leaf area, and TSS are given in Table 2; membrane damage index and leaf relative water content values are given in Table 3 and some nutrient (K, $\mathrm{Ca}, \mathrm{Na}$, $\mathrm{Zn}, \mathrm{Cu}$ and $\mathrm{Mn}$ ) content values are indicated in Table 4.

Chemical fertilizer application had generally higher and significant values than the control application on plant growth parameter of garden rocket (Table 2). Microalgae application had also generally higher and significant values than the nil application on plant growth parameter of garden rocket (Table 2). For the shoot fresh and dry weight values of the $50 \%$ and $100 \%$ fertilizer application were considerably higher than $0 \%$ fertilizer application. Microalgae application caused also insignificant increase in the shoot fresh and dry weight values compared to no microalgae application. Microalgae application caused significant $(\mathrm{P} \leq 0.01)$ increases (about $34 \%$ and $20 \%$ ) in stem diameter and shoot height in garden rocket, respectively (Table 2). While the $50 \%$ and $100 \%$ fertilizer application caused significant increase in shoot height, only $50 \%$ of fertilizer application significantly increased the stem diameter in garden rocket (Table 2).

Microalgae application caused also significant $(\mathrm{P} \leq 0.01)$ increases (about $45 \%$ and $14 \%$ ) in TSS and leaf area in garden rocket, respectively (Table 2). Fertilizer application had significant increases in leaf area in garden rocket. The interaction of microalgae and fertilizer application was found significant in TSS and leaf area in garden rocket. The highest TSS value (5.97 brix ${ }^{0}$ ) was determined in microalgae application with nil fertilizer application, and this were followed by the other microalgae applications. The highest leaf area value $\left(41.95 \mathrm{~cm}^{2}\right.$ plant $\left.{ }^{-1}\right)$ was determined in microalgae application with $50 \%$ fertilizer application, and this were followed by the microalgae application with $100 \%$ fertilizer application (Table 2). The positive effects of microalgae applications on plant growth have been observed in many vegetable species. Hassan et al. (2017) stated that the foliar spraying with Cyanobacterium Spirulina platensis, blue green algae, at $5 \%$ had positively significant effects on plant height, numbers of leaves, chlorophyll a and $b$, rocket comparing to N-P-K control treatment, In a study examining the effects on plant growth by using Chlorella vulgaris in tomato, it was determined that positive increases were observed on plant growth, shoot fresh weight, stem diameter, shoot dry weight, shoot length and TSS amount (Özdemir et al., 2016). It has been reported that microalgae applications to lettuce seedlings significantly increase shoot fresh and shoot dry weight, shoot length and stem diameter (Faheed et al., 2008). It was observed that the plant fresh and dry weight, shoot length, leaf area and stem diameter values of microalgae application to tomato seedlings increased compared to the control group (Anitha et al., 2016). In a study in which different doses of fertilizers and microalgae (Chlorella vulgaris) applications were applied in lettuce cultivation, it was reported that microalgae applied groups had increasing effects on leaf area, stem diameter, shoot length, shoot fresh and dry weight values compared to other application groups (Ergun et al., 2020).

Membrane damage index and leaf relative water content values examined in this study, which was conducted to investigate the effects of microalgae and two different fertilizer doses on garden rocket plant growth, are discussed below (Table 3). Considering the membrane damage index values, it was determined that the effect of microalgae applications was generally positive. It was determined that the differences between the values of the membrane damage index microalgae application group and the control group were statistically significant $(\mathrm{P} \leq 0.01)$. There are also statistically significant differences between microalgae applications and microalgae + fertilizer interaction values.

Microalgae application caused significant $(p \leq 0.01)$ decrease (about 59\%) in membrane damage index in garden rocket (Table 3 ). The lowest membrane damage index value $(8.33 \%)$ was determined in microalgae application with nil fertilizer application, and microalgae applications with the $50 \%$ and $100 \%$ fertilizer application had also lower membrane damage index values $(14.15 \%$ and $18.58 \%$, respectively) compared to other applications having no microalgae. There were also some insignificant increases in leaf relative water content in microalgae applied garden rocket (Table 3).

Due to their high protein content, microalgae provide significant advantages for plants in cell growth and development, and enable cell protection and repair, regulation of cellular activities, and the activation of defense mechanisms against chemical signals and negativity in adverse environmental conditions (Solomon, 1999; Koru et al., 2005; Özdemir, 2014). In a study on tomato, it was stated that while abiotic stresses showed a decrease in leaf relative water content values in plants, there was an increase in microalgae application values (Munns, 2005). Again, according to the values obtained from plants exposed to stress conditions, microalgae applications stand out among the application groups with the least damage among the membrane damage index values (Zodape et al., 2011).

Table 3. Effect of microalgae application on membrane damage index and (\%) leaf relative water content of garden rocket grown with different doses of chemical fertilizer

\begin{tabular}{|c|c|c|c|c|c|c|}
\hline \multirow{3}{*}{ Chemical Fertilizer } & \multicolumn{3}{|c|}{ Membrane damage index (\%) } & \multicolumn{3}{|c|}{ Leaf relative water content (\%) } \\
\hline & \multicolumn{2}{|c|}{ Microalgae } & \multirow{2}{*}{ Mean } & \multicolumn{2}{|c|}{ Microalgae } & \multirow{2}{*}{ Mean } \\
\hline & - & + & & - & + & \\
\hline $0 \%$ (Control) & $39.63^{\mathrm{a}^{*}}$ & $8.33^{\mathrm{f}}$ & $23.98^{\mathrm{ns}}$ & $74.61^{\mathrm{ns}}$ & 83.36 & $78.98^{\text {ns }}$ \\
\hline $50 \%$ & $29.43^{\mathrm{c}}$ & $14.15^{\mathrm{e}}$ & 21.79 & 79.64 & 85.25 & 82.44 \\
\hline $100 \%$ & $30.28^{\mathrm{b}}$ & $18.58^{\mathrm{d}}$ & 24.43 & 68.95 & 79.68 & 74.31 \\
\hline Mean & $33.11^{\mathrm{A}^{* *}}$ & $13.68^{\mathrm{B}}$ & & $74.40^{\mathrm{ns}}$ & 82.76 & \\
\hline
\end{tabular}

ns: not significant, *: Significant at $\mathrm{P} \leq 0.05, * *$ : Significant at $\mathrm{P} \leq 0.01$ 
Table 4. Effect of microalgae application on some nutrient contents of garden rocket grown with different doses of chemical fertilizer

\begin{tabular}{|c|c|c|c|c|c|c|}
\hline \multirow{3}{*}{ Chemical fertilizer } & \multicolumn{3}{|c|}{$\mathrm{K}(\mathrm{ppm})$} & \multicolumn{3}{|c|}{$\mathrm{Ca}(\mathrm{ppm})$} \\
\hline & \multicolumn{2}{|c|}{ Microalgae } & \multirow{2}{*}{ Mean } & \multicolumn{2}{|c|}{ Microalgae } & \multirow{2}{*}{ Mean } \\
\hline & - & + & & - & + & \\
\hline $0 \%$ (Control) & $4655^{\text {ns }}$ & 6082 & $5368^{\mathrm{C**}}$ & $3578^{\text {ns }}$ & 3979 & $3778^{\mathrm{C}^{*}}$ \\
\hline $50 \%$ & 6048 & 7300 & $6674^{\mathrm{B}}$ & 3999 & 5419 & $4709^{\mathrm{B}}$ \\
\hline $100 \%$ & 6482 & 8225 & $7353^{\mathrm{A}}$ & 4018 & 7945 & $5981^{\mathrm{A}}$ \\
\hline Mean & $5728^{\mathrm{B}^{* * *}}$ & $7202^{\mathrm{A}}$ & & $3865^{\mathrm{B}^{* * *}}$ & $5781^{\mathrm{A}}$ & \\
\hline \multirow{3}{*}{ Chemical fertilizer } & \multicolumn{3}{|c|}{$\mathrm{Na}(\mathrm{ppm})$} & \multicolumn{3}{|c|}{$\mathrm{Zn}(\mathrm{ppm})$} \\
\hline & \multicolumn{2}{|c|}{ Microalgae } & \multirow{2}{*}{ Mean } & \multicolumn{2}{|c|}{ Microalgae } & Mean \\
\hline & - & + & & - & + & MVeall \\
\hline $0 \%$ (Control) & $2982^{\text {ns }}$ & 2516 & $2749^{\mathrm{B}^{\mathrm{**}}}$ & $5.030^{\text {ns }}$ & 6.887 & $5.958^{\text {ns }}$ \\
\hline $50 \%$ & 4449 & 2938 & $3693^{\mathrm{AB}}$ & 6.255 & 6.910 & 6.567 \\
\hline $100 \%$ & 5531 & 3026 & $4278^{\mathrm{A}}$ & 6.760 & 7.390 & 6.538 \\
\hline Mean & $4320^{\mathrm{A}^{*}}$ & $2826 \mathrm{~B}$ & & $6.015^{\mathrm{B}^{* *}}$ & $7.062^{\mathrm{A}}$ & \\
\hline \multirow{3}{*}{ Chemical fertilizer } & \multicolumn{3}{|c|}{$\mathrm{Cu}(\mathrm{ppm})$} & \multicolumn{3}{|c|}{$\mathrm{Mn}(\mathrm{ppm})$} \\
\hline & \multicolumn{2}{|c|}{ Microalgae } & \multirow{2}{*}{ Mean } & \multicolumn{2}{|c|}{ Microalgae } & Mean \\
\hline & - & + & & - & + & Ivicair \\
\hline$\overline{0 \%}$ (Control) & $3.427^{\mathrm{ns}}$ & 3.465 & $3.446^{\mathrm{ns}}$ & $35.93^{\mathrm{ns}}$ & 31.86 & $33.90^{\text {ns }}$ \\
\hline $50 \%$ & 5.190 & 4.042 & 4.534 & 27.64 & 32.14 & 30.21 \\
\hline $100 \%$ & 4.530 & 4.777 & 4.653 & 34.17 & 31.95 & 33.06 \\
\hline Mean & $4.309^{\mathrm{ns}}$ & 4.095 & & $33.03^{\text {ns }}$ & 31.98 & \\
\hline
\end{tabular}

ns: not significant, *: Significant at $\mathrm{P} \leq 0.05$, **: Significant at $\mathrm{P} \leq 0.01$

In the present study, some nutrient $(\mathrm{K}, \mathrm{Ca}, \mathrm{Na}, \mathrm{Zn}, \mathrm{Cu}$ and $\mathrm{Mn}$ ) contents of garden rocket grown with different doses of chemical fertilizer and microalgae application were determined and listed in Table 4.

The effect of microalgae use on nutrient content was especially positive for $\mathrm{K}, \mathrm{Ca}, \mathrm{Na}$, and $\mathrm{Zn}$. Microalgae application caused significant $(\mathrm{P} \leq 0.01)$ increase (about $36 \%$ ) in $\mathrm{K}$ content of garden rocket (Table 4). Similarly, microalgae application caused significant $(\mathrm{P} \leq 0.05)$ increase (about 50\%) in Ca content of garden rocket (Table 4). However, and fortunately microalgae application caused significant $(\mathrm{P} \leq 0.05)$ decrease (about $35 \%)$ in $\mathrm{Na}$ content of garden rocket (Table 4). Moreover, fertilizer applications significantly increased the contents of $\mathrm{K}, \mathrm{Ca}$, and Na. Sayed Ahmed et al. (2021) reported that Cholorella could increase nutrient content of garden rocket through upregulation of key genes in their biosynthetic pathway. Agwa et al. (2017) stated that Chlorella vulgaris as a bio-fertilizer is efficient and economical in improving soil nutrients for greater productivity of okra. In a study, investigating the effect of microalgae use on plant nutrient content in tomato seedlings, the effect on zinc, potassium and calcium content was investigated, and it was stated that the use of microalgae increased significantly these nutrients (Anitha et al., 2016). The effect of microalgae on plant growth and nutrient content of lettuce seedlings was investigated and it was reported that microalgae generally increased yield and $\mathrm{Ca}$ and $\mathrm{K}$ contents in lettuce seedlings (Grouch et al., 1990). In another study examining the effect of microalgae on tomato plants, nutrient content increased significantly compared to control plants (Zodape et al., 2011). Hassan et al. (2021) reported that seaweed extract could generally stimulate morpho-agronomic and bioactive properties of garden rocket and be used as multifunctional bio-fertilizer. Bio-fertilizers have an important place in the development of plant growth, soil fertility and environmental factors in a sustainable agriculture (Verdieri et al., 2006; Singh et al., 2016; Godlewska et al., 2019). It is also stated that bio-stimulants also reduce harmful substance for plant and human health (Verdieri et al., 2006). It has been determined that microalgae applied to seedlings and plants play an important role in increasing the nutrient content and improving plant growth characteristics (Jardin, 2015).

The rhizosphere microorganisms could interact with each other over multifold ways and responding of the surrounding environments. Although, we have not studied, it is known that microalgae could also establish mutualistic interactions with AMF and bacteria (Hristozkova et al., 2018; Abinandan et al., 2019; Kang et al., 2021). Hristozkova et al., (2018) reported that dual inoculation with both microalgae and AMF stimulated mycorrhizal function (concentration of glomalin-related proteins) and improved plant performance both directly and indirectly through mycorrhizal stimulation. Kang et al. (2021) reviewed that microalgae and plant growth-promoting bacteria (PGPB) were recognized as substitutes to chemical fertilizers for improving soil fertility due to their bio-fertilizing properties, through the production of bioactive compounds (e.g., phyto-hormones, amino acids, and carotenoids) and also their ability to prevent plant pathogens. Abinandan et al. (2019) reviewed that microlagae could have potential soil traits as carbon fixation, extracellular polysaccharides and initiation of biological soil crust, and dual inoculation with both microalgae (Chlorella sp.) and cyanobacteria was a very helpful factor for soil fertility especially in marginal soil by improving nitrogen and soil enzyme activities, and microbial biomass.

\section{Conclusion}

In the present study, in which the effect of microalgae [Chlorella vulgaris Beyerinck (Beijerinck)] use on plant growth in garden rocket (Eruca vesicaria ssp. sativa Mill.) was investigated, the effect of microalgae, defined as biofertilizer, was found to be generally positive for plant growth. There were significant differences between the 
values of microalgae applications and non-microalgae applications in many examined parameters. Microalgae application together with $50 \%$ fertilizer application also gave better results than $100 \%$ fertilizer application in terms of some studied traits (such as leaf area, membrane damage index, LRWC and $\mathrm{Na}$ content). In parallel with the increasing population in the world, the need for food also increases, and as a result of increased pressures, the continuous and intensive use of chemical fertilizers causes the consumption of natural resources and the deterioration of the ecological balance. In the face of this situation, agricultural lands are destroyed, the amount of the product produced decreases and also the quality of the product decreases. With the use of bio-fertilizers, both the use of chemical fertilizers will be reduced and the destruction of agricultural lands will be prevented. Thus, there will be no problems in sufficient food production and resources will not be consumed. It is thought that as the number of studies on the relationship between microalgae and plants increases, newer insight will be discovered for much more sustainable agriculture. In future studies, it will be useful to study the mutualistic relationships of other beneficial microorganisms such as AMF and PGPR with microalgae and rhizosphere in detail.

\section{Acknowledgements}

We thank to Cukurova University, Faculty of Fisheries for microalgae supply.

\section{References}

Abinandan SSR, Subashchandrabose K, Venkateswarlu M, Megharaj M. 2019. Soil microalgae and cyanobacteria: the biotechnological potential in the maintenance of soil fertility and health. Critical reviews in biotechnology, 39(8): 981-998.

Ağırman N. 2015. The Effects of Different Stress Factors on the Development, Pigment Formation, Lipid and Protein Content of Chlorella vulgaris and Scenedesmus acutus (doctoral dissertation). Firat University Institute of Science and Technology. Elazig.

Agwa O, Ogugbue K, Williams C. 2017. Field evidence of Chlorella vulgaris potentials as a biofertilizer for Hibiscus esculentus. Int J Agric Res, 12(4): 181-189.

Anitha L, Sai Bramari G, Kalpana P. 2016 Effect of supplementation of Spirulina platensis to enhance the zinc status in plants of Amaranthus gangeticus, Phaseolus aureus and tomato. Advances in Bioscience and Biotechnology, 7:289-299.

Aydoner Coban G, Dasgan HY, Akhoundnejad Y, Ak Cimen B. 2018. Use of microalgae (Chlorella vulgaris) to save mineral nutrients in soilless grown tomato. In XXX International Horticultural Congress IHC2018: II International Symposium on Soilless Culture and VIII International 1273 (pp. 161-168).

Balc1 T. 2019. Heavy Metal Stress in Roket (Eruca sativa L.) Effect on Plant Development and Physiology. (Master's Thesis, Atatürk University, Institute of Science and Technology).

Barazani O, Ziffer-Berger J. 2014. Eruca sativa, a Tasty Salad Herb with Health-Promoting Properties. In Medicinal and Aromatic Plants of the Middle-East (pp. 269-279). Springer, Dordrecht.

Beck LY. 2005. Altertumswissenschaftliche Texte und Studien Pedanius Dioscorides of Anazarbus De Materia Medica (38th ed.), Hildesheim, Georg Olms Verlag AG.

Cirik Ş, Cirik S. 1999. Aquatic plants: I ecology, biology and cultivation techniques of marine plants. Ege University, Faculty of Fisheries Publications, 58: 135-145. (In Turkish).
Duncan DB. 1955. Multiple range and multiple $\mathrm{F}$ test. Biometrichs, 11: 1-42.

Duygu Y, Udoh AU, Özer T, Erkaya IA. 2017. The characteristics and importance of microalgae culture collections. Journal of Süleyman Demirel University Eğirdir Fisheries Faculty, 13(1): 80-87.

Engin YÖ, Yağmur B, Cirik S, Okur B, Eşiyok D, Gökpınar Ş. 2019. Ulva rigida (C. Agardh) makroalginin fasulye bitkisinin üretiminde organik madde kaynağı olarak kullanımının araştırılması. Acta Aquatica Turcica, 15(2): 151-162.

Ergün O, Daşgan HY, Işık O. 2020. Effects of micromikroalgae Chlorella vulgaris on hydroponically grown lettuce. Acta Horticulturae 1273: 169- 176. XXX IHC - Proc. II International Symposium on Soilless Culture, doi 10.17660/ActaHortic.2020.1273.23.

Eşiyok D. 2012. Winter and Summer Vegetable Cultivation. 404 p. Bornova/Izmir. (In Turkish).

Eşiyok D, Yağmur B, Okur B. 2001. The effects of some naturel and mineral fertilizers on yield and mineral content of parsley (Petroselinum crispum Mill.). 37th Croatian symposium on agriculture with an int. participation. 19-23 February. Opatija, 179-181.

Faheed AF, Abd-El Fattah Z. 2008. Effect of Chlorella vulgaris as biofertilizer on growth parameters and metabolic aspects of lettuce plant. J. Agric. Soc. Sci, 4(4): 165-169.

Godlewska K, Michalak I, Pacyga P, Basladynska S, Chojnacka K. 2019. Potential applications of cyanobacteria: Spirulina platensis fltrates and homogenates in agriculture, World Journal of Microbiology and Biotechnology, 35:80.

Grouch IJ, Beckett RP, Staden JV. 1990. Effect of Seaweed Concentrate on the Growth and Mineral Nutrition of Nutrient- Stressed Lettuce. Journal of Applied Phycology, 2: 269-272.

Hassan SM, Ashour M, Soliman AF. 2017. Anticancer Activity, Antioxidant Activity, Mineral Contents, Vegetative and Yield of Eruca sativa Using Foliar Application of Autoclaved Cellular Extract of Spirulina platensis Extract, Comparing to NPK Fertilizers. Journal of plant Production, 8(4): 529-536.

Hassan SM, Ashour M, Soliman AA, Hassanien HA, Alsanie WF, Gaber A, Elshobary ME. 2021. The potential of a new commercial seaweed extract in stimulating morphoagronomic and bioactive properties of Eruca vesicaria (L.) Cav. Sustainability, 13(8): 4485.

Hristozkova ML, Gigova M, Geneva I, Stancheva V, Velikova G, Marinova G. 2018. Influence of mycorrhizal Fungi and microalgae dual inoculation on basil plants performance. Gesunde Pflanzen, 70(2): 99-107.

IBM SPSS. http://www.ibm.com/tr-tr/analytics/spss-statisticssoftware.

Jardin P. 2015. Plant biostimulants: Definition, concept, main categories and regulation. Scientia Horticulturae, 196: 3-14.

Kacar B. 1997. Chemical Analysis of Plant and Soil A.Ü.Z.F. Publications No: 453, Ankara. (In Turkish)

Kacar B, İnal A. 2008. Plant analysis. Nobel Publication Distribution. (In Turkish).

Kang YM, Kim C, Shim S, Bae S, Jang S. 2021. Potential of Algae-Bacteria Synergistic Effects on Vegetable Production. Frontiers in Plant Science, 12: 556.

Koru E, Cirik S. 1999. Use of algae in agriculture and industry. Turkey 1st Ecological Agriculture Symposium, 21-23 June 1999, İzmir, 344. (In Turkish)

Koru E, Cirik S, Turan G, Tekoğul H, Karacalar US, Yıldız, Ş. 2005. Development of production technologies of some economical algae species. University-Industry Collaboration Project, İzmir, 146p. (in Turkish)

Kusvuran S. 2010. Relationships between physiological mechanisms for drought and salinity tolerance of melons. Unpublished Ph.D. Thesis. Çukurova University Institute of Natural and Applied Sciences, 356p. 
Kusvuran Ş, Ellialtioglu SS. 2021. Assessment of different organic matters on antioxidative enzyme activities and nutritional components under salt stress in salad rocket (Eruca sativa). Journal of Animal Plant Sciences, 31(5): 2021, Page: 1319-1328

Kut GB, Cirik Ş, Güroy D, Sanver F, Tekinay AA. 2007. Effects of Ulva rigida or Cystoseira barbata meals as a feed additive on growth performance, feed utilization, and body composition in Nile tilapia, Oreochromis niloticus". Turkish Journal of Veterinary and Animal Science, 31(2): 91-97.

Morales M, Janick J. 2002. Arugula: A promising specialty leaf vegetable. Trends in new crops and new uses. ASHS Press, Alexandria, VA, 418-423.

Munns R. 2005. Genes and Salt Tolerance: Bringing Them Together. New Phytologist, 167: 645-663.

Midmore DJ. 1993. Agronomic modification of resource use and intercrop productivity. Field Crops Research, 34: 357-380.

Okur B, Eşiyok D, Anaç D. 2001. Effect of mineral and organic fertilizers on leaf nitrogen compounds of rocket (Eruca vesicaria sub sp. sativa mill). 37th Croatian Symposium on Agriculture. 19-23 February, Opatija-Croatia. 188-189.

Özdemir S. 2014. The effects of the use of Chlorella vulgaris beyerinck [Beijerinck] as a biofertilizer on plant growth, yield and fruit quality in greenhouse organic tomato cultivation. Ege University, Institute of Science and Technology, İzmir. 91s. (in Turkish).

Özdemir S, Sukatar A, Öztekin GB. 2016. Production of Chlorella vulgaris and the effects of its use as a biofertilizer in greenhouse organic tomato cultivation. Journal of Agricultural Sciences. 22(4): 596-605. (In Turkish).

Santamaria P, Elia A, Parente A, Serio F. 1998. Fertilization strategies for lowering nitrate content in leafy vegetables: chicory and rocket salad cases. Journal of plant nutrition, 21(9): 1791-1803.
Sayed Ahmed HI, Elsherif DE, El-Shanshory AR, Haider AS, Gaafar RM. 2021. Silver nanoparticles and Chlorella treatments induced glucosinolates and kaempferol key biosynthetic genes in Eruca sativa. Beni-Suef University Journal of Basic and Applied Sciences, 10(1): 1-15.

Sencar Ö. 1988. The Effects of Sowing Frequency and Nitrogen in Corn Cultivation. Tokat Faculty of Agriculture Publication No: 6, Scientific Research and Investigations No: 3, Tokat. (In Turkish).

Solomon EP, Berg LR, Martin DW. 1999. Biology 5th ed. Fort Worth: Saunders Collage Publishing.

Singh JS, Kumar A, Rai AN, Singh DP. 2016. Cyanobacteria: a precious bio-resource in agriculture, ecosystem, and environmental sustainability. Frontiers in Microbiology 7:529.

Şalk A, Arin L, Deveci M, Polat S. 2008. Special Vegetables. Tekirdağ: Onur Graphics Printing and Advertising Services. (In Turkish).

Temel E. 2016. Iodine Enrichment of Garden Rocket Plant by Leaf Application. (Master's Thesis, Çanakkale Onsekiz Mart University Institute of Science and Technology). (In Turkish).

Turan G. 2007. Use of algae in thalassotherapy. E.U. Institute of Science Department of Aquaculture, Ph.D. Thesis, 125-129. (In Turkish).

Vernieri P, Borghesi E, Tognoni F, Serra G, Ferrante A, Piagessi A. 2006. Use of biostimulants for reducing nutrient solution concentration in floating system. In III International Symposium on Models for Plant Growth, Environmental Control and Farm Management in Protected Cultivation 718 (pp. 477-484).

Zodape ST, Gupta A, Bhandarı SC, Rawat US, Chaudhary DR, Eswaran K, Chıkara J. 2011. Foliar application of seaweed sap as biositimulant for enhancement of yield and quality of tomato. Journal of Scientific Industrial Research, Vol. 70, pp. 215- 219. 